\title{
SOME NOMENCLATURAL CHANGES REGARDING PERUVIAN ENDEMICS
}

\author{
EduARdo Antonio Molinari-NovoA
}

\begin{abstract}
The nomenclature of one section, seven species and one subspecies of Peruvian endemic plants is reviewed, and the corresponding changes are proposed.
\end{abstract}

Key words: Crinum, Ilex, Junellia, Markea, Nasa, Poa, Ternstroemia, Verbena, new combination, new subspecies

Eduardo Antonio Molinari-Novoa, Herbario (MOL), Departamento Académico de Biología, Universidad Nacional Agraria La Molina, Avenida La Universidad, Apartado 456, Lima 12, Peru; e-mail: 20090095@lamolina.edu.pe

\section{INTRODUCTION}

In the course of a bibliographic revision on Peruvian endemics it became apparent that some nomenclatural changes were needed in order to provide correct names for some Peruvian taxa. These changes have been delayed for years, and are urgent since the Peruvian government is currently organising the 'Actualisation Process for the Categorisation of Threatened Wild Flora Species in Peru'. The creation of these nomenclatural novelties is aimed to avoid legal problems by providing a unique, correct name for these plants.

\section{RESULTS}

Crinum ugentii (Ochoa) Molinari, comb. nov.

Basionym: Hippeastrum ugentii Ochoa, Phytologia 88(2): 176. 2006 (September).

This herb, endemic from Huancavelica, has been indicated as belonging to the genus Crinum L. by Govaerts (2011). Analysis of the isotype at MOL (Ochoa 16402) and the description by Ochoa (2006) lead us to confirm this taxonomic opinion: the multiflowered inflorescence, with white tepals facing downwards, clearly exclude this species from the genus Hippeastrum Herb. Since it is only known from the type, it should be catalogued as 'Data Deficient'.
Ilex perulera Molinari, nom. nov.

RePlaced name: Ilex crassifolia Hook., Icon. Pl. 2: t. 149.1837 (April), non Ilex crassifolia Meerb., Pl. Select. Ic. Pict. 6: t. 4. 1798.

This tree, endemic to Amazonas Department in northern Peru, is a good species, recognized by León (2007a) as 'Endangered'. The adjective 'perulera, -us, -um' is an archaism for 'Peruvian' and is proposed because the distribution of this species is limited to that country.

Junellia alba (Moldenke) Molinari, comb. et stat. nov.

Basionym: Verbena occulta f. alba Moldenke, Bull. Torrey Bot. Club 77: 405. 1950.

This small, pubescent shrub is endemic to the Andes of central Peru, and due its wide distribution should be catalogued as of 'Least Concern'. Binder (2002) considered this form as deserving specific rank within the genus Verbena L., and remarked its close relationship with $V$. fasciculata Benth., currently named $J$. fasciculata (Benth.) N. O'Leary \& P. Peralta (O'Leary et al. 2009). Following both proposals, here it is combined as a species within Junellia Moldenke. A fragmentary isotype (Ferreyra 6485) is at MOL. 
Markea klugii (Hunz.) Molinari, comb. nov.

BASIONYM: Hawkesiophyton klugii Hunz., Kurtziana 10: 40. 1977.

Knapp et al. (1997) recognized this species as part of the genus Markea Rich. but no combination has been published so far. This climbing shrub is endemic to Loreto Department and Ucayali Department in eastern Peru, and is considered 'Endangered' (Knapp et al. 2007).

\section{Nasa picta (Hook.) Molinari, comb. nov.}

BASIONYM: Loasa picta Hook., Bot. Mag. 75: t. 4429. 1849.

Nasa picta has been published twice (Weigend 1998; Weigend et al. 2006). However, in both instances the combinations were made without the basionym's date of publication, rendering them not validly published. This herb is endemic to northern Andean departments of Peru: Amazonas, Áncash, Cajamarca, La Libertad and Piura (Rodríguez \& Weigend 2007), and has been catalogued as of 'Least Concern'.

Nasa picta has a subspecies that was also not validly published by Weigend and Rodríguez (2000) and then by Weigend et al. (2006). We choose to validate it here, using the same data and proposing a correct Latin ending for it.

Nasa picta subsp. pamparomasensis E. Rodr. \& Weigend ex Molinari, subsp. nov.

A subspecies typica similis sed sparse setosis et bracteis linearilanceolatis vel trifoliatis differt.

Type: PERÚ, Depto. Áncash, Prov. Huaylas, Distr. Pamparomás: Carretera Karka - Pamparomás, $09^{\circ} 03^{\prime} 03^{\prime \prime} \mathrm{S}, 77^{\circ} 58^{\prime} \mathrm{W}, 05.05 .2000$, Weigend \& Salas 2000/619 (HOLOTYPE: USM: ISOTYPES: HUT, M, F, NY).

Since the species was not validly published, this subordinate taxon was considered invalid. It was catalogued as 'Vulnerable' by Rodríguez and Weigend (2007).

Poa sect. Tovarochloa (T. D. Macfarl. \& But) Molinari, comb. et stat. nov.

BAsionym: Tovarochloa T. D. Macfarl. \& But, Brittonia 34(4): 478. 1982 (December 17).
TyPe SPeCIES: Poa apiculata Refulio.

Tovarochloa T. D. Macfarl. \& But was a monotypic, endemic genus of uncertain affinities. Created by a descriptio generico-specifica in 1982, it was stated that it superficially resembled $A n$ thochloa lepidula Nees \& Mayen, and was located in Agrostidae (Macfarlane \& But 1982). Later, Clayton and Renvoize (1986) suggested probable affinities with Dissanthelium Trin. Nowadays it is considered to be within Poa sensu lato and to constitute a single-species section, as proposed by Refulio-Rodríguez et al. (2012), who transferred the genus along with Dissanthelium as sections of Poa L. However, the change of status was made without a reference to the basionym, and was thus not validly published. Since it is an important and rather peculiar plant, deserving its own section, we validate the change here. The species, widespread and common in southern Peru (and probably occurring in Bolivia), must be designated as of 'Least Concern'.

Ternstroemia compacta (J. F. Macbr.) Molinari, comb. nov.

BASIONYM: Symplocos compacta J. F. Macbr., Candollea 5: 399. 1934.

This species, originally published as a member of Symplocaceae, was not considered a Symplocos Jacq. by Ståhl (1995) in his genus treatment, and was indicated as closely related to $T$. quinquepartita Ruiz \& Pav. by León (2007b). In the same paper it was stated that no samples of this plant were available in a Peruvian herbarium. However, in the course of this research an isotype (Weberbauer 6731) was found at MOL. This species is endemic to Cerro de Pasco Department in central Peru, and was evaluated as 'Data Deficient'.

Verbena cajamarcensis Binder ex Molinari, nom. et stat. nov.

REPLACED NAME: Verbena minutiflora var. peruviana Moldenke, Phytologia 50: 14. 1981, non Verbena peruviana (L.) Britton, Ann. New York Acad. Sci. 7: 197. 1893.

Binder (2002) proposed that $V$. minutiflora var. peruviana deserved specific rank. However, 
the nomenclatural change was never enacted until now. This herb is closely related to $V$. litoralis Kunth, and is endemic to northern Peru. Since it is possible to find this taxon in Ecuador, it is catalogued as 'Not Evaluated' until its geographic range is studied.

ACKNOWLEDGEMENTS. I am grateful to the anonymous reviewers for helpful remarks and suggestions on the manuscript.

\section{REFERENCES}

BINDER M. 2002. Verbena L., Glandularia Gmel., Junellia Moldenke, Lantana L. und Lippia L. (Verbenaceae) in Peru. PhD Thesis, Faculty of Biology, Ludwig-Maximilian University, Munich. http://edoc.ub.uni-muenchen. de/1400/1/Binder_Michaela.pdf

Clayton W. D. \& Renvoize S. A. 1986. Genera Graminum: Grasses of the world. Kew Bull., Addit. Ser. 13: 1-389.

Govaerts R. H. A. 2011. World checklist of Amaryllidaceae. Facilitated by the Trustees of the Royal Botanic Gardens, Kew. [22 June 2015]. http://apps.kew.org/wcsp/nonacceptedRef.do?name_id=347115

Knapp S. \& Helgason T. 1997. A revision of Solanum section Pteroidea: Solanaceae. Bull. Nat. Hist. Mus. London, Bot. 27(1): 31-73.

Knapp S., Spooner D. M. \& León B. 2007. Solanaceae endémicas del Perú. Revista Peru. Biol. 13(2): 612s-643s.

León B. 2007a. Aquifoliaceae endémicas del Perú. Revista Peru. Biol. 13(2): 49s-50s.
León B. 2007b. Theaceae endémicas del Perú. Revista Peru. Biol. 13(2): $650 \mathrm{~s}-651 \mathrm{~s}$.

O’Leary N., Yuan Y.-W., Chemisquy A. \& Olmstead R. G. 2009. Reassignment of species of paraphyletic Junellia s.1. to the new genus Mulguraea (Verbenaceae) and new circumscription of genus Junellia: molecular and morphological congruence. Syst. Bot. 34(4): 777-786.

Macfarlane T. D. \& But P. P.-H. 1982. Tovarochloa (Poaceae: Pooideae), a new genus from the high Andes of Peru. Brittonia 34(4): 478-481.

OCHOA C. 2006. Hippeastrum ugentii (Amaryllidaceae: Hippeastreae): a new species from central Peru. Phytologia 88(2): 176-178.

Refulio-Rodríguez N. F., Columbus J. T., Gillespie L. J., PeTERSON P. M. \& SORENG R. J. 2012. Molecular phylogeny of Dissanthelium (Poaceae: Pooideae) and its taxonomic implications. Syst. Bot. 37(1): 122-133.

Rodríguez E. \& Weigend M. 2007. Loasaceae endémicas del Perú. Revista Peru. Biol. 13(2): 391s-402s.

STÅHL B. 1995. New or noteworthy Andean species of the genus Symplocos (Symplocaceae). Candollea 50: 445-452.

Weigend M. 1998. Nasa y Presliophytum: Los nombres y sus tipos en los nuevos generous segregados de Loasa Juss. senso Urban \& Gilg en Perú. Arnaldoa 5(2): 159-170.

Weigend M. \& Rodriguez-R. E. 2000. Nasa picta Hook.f. subsp. pamparomasii (Loasaceae), a new subspecies of Nasa picta from Ancash, Peru. Arnaldoa 7(1): 19-26.

Weigend M., Dostert N., Henning T., Schneider C. \& RoDRÍGUEZ E. F. 2006. Valid publication for 101 species and subspecies names of the genera Nasa and Aosa (Loasaceae: Cornales). Revista Peru. Biol. 13(1): 71-84. 